\title{
Electrical energy transition in the context of Ghana
}

\author{
Paul Osei-Tutu* ${ }^{*}$, Samuel Boadi and Vincent Kusi-Kyei
}

\begin{abstract}
Background: In Ghana, energy transition as a research theme is new. It is unclear whether energy transition has occurred or not, and if so, in what form. This study sought to find out whether this transition has occurred in Ghana's electrical energy sector and how using indicators deduced from literature, such as change in energy source type, change in energy ownership and management, and transition to greener vehicular transportation.

Methods: Information on Ghana's electrical energy transition was obtained from thematic content analysis of Ghana's renewable energy policy documents, energy sector reports, newspaper articles and information on the websites of Ghana's energy sector institutions such as the Volta River Authority, Ghana Grid Company Limited, Electricity Company of Ghana and the Northern Electricity Distribution Company.

Results: In this study, it was demonstrated that two structural changes have occurred in Ghana's electrical energy sector: (1) Transition from an exclusively hydro energy to a hydro-thermal mix, with thermal energy constituting about 69\% of the 2020 generation mix; and (2) Transition from an exclusively state supplied energy to a state-private supply mix, with about $56 \%$ of the 2020 supply coming from private companies. These changes were motivated by the need to expand the energy supply in response to an increasing demand of 10-15\% per year. The study also indicated that renewable energy had attracted attention in policy, with policy targets such as $10 \%$ renewable energy in the energy mix by 2030 and provision of renewable energy to 1000 off-grid communities by 2030. However, renewable energy currently constitutes less than $1 \%$ of the electrical energy mix. Also, there has been no change in the heavy reliance on fossil energy for vehicular transportation.
\end{abstract}

Conclusions: The study concludes that energy transition in its broad sense of structural changes in a country's electrical energy system has occurred in Ghana, however a sustainable energy transition in the sense of a transition to greener energy has not occurred. It is recommended that further studies should be conducted on why Ghana's renewable energy agenda has so far only been an agenda in policy with very minimal implementation in practice.

Keywords: Energy transition, Green energy, Electrical energy, Ghana

\section{Background}

\section{Background to the study and study objective}

Energy transition has emerged as an important theme within energy governance literature and practice. This is happening against a background of growing movement to green energy as the world strives to maintain greenhouse

*Correspondence: posei-tutu@knust.edu.gh

Faculty of Renewable Natural Resources, Kwame Nkrumah University

of Science and Technology, Kumasi, Ghana gas emissions and global warming within limits [1]. For instance in Germany, the energy transition agenda, called 'Energiewende', has taken firm roots: supportive policies and legislation have been introduced; nuclear power plants have been shut down; the proportion of green energy in the energy mix has increased significantly; there is a localized production and distribution of energy; vehicles with higher emissions have restricted access to certain places; and diesel cars are being banned in some places [2]. In some countries, electricity is replacing fossil original author(s) and the source, provide a link to the Creative Commons licence, and indicate if changes were made. The images or other third party material in this article are included in the article's Creative Commons licence, unless indicated otherwise in a credit line to the material. If material is not included in the article's Creative Commons licence and your intended use is not permitted by statutory regulation or exceeds the permitted use, you will need to obtain permission directly from the copyright holder. To view a copy of this licence, visit http://creativecommons.org/licenses/by/4.0/. The Creative Commons Public Domain Dedication waiver (http://creativecommons.org/publicdomain/zero/1.0/) applies to the data made available in this article, unless otherwise stated in a credit line to the data. 
fuels in powering vehicular transportation within and between the cities [2].

Although there is no universally accepted definition for the term "Energy Transition" [3], it has been described as an inevitable shift away from cheap, centralized, largely fossil-based energy systems [4]. The literature with regard to energy transition shows two categories of definitions for the term. The first category defines energy transition as a structural change in a country's energy system [5]. Structural change here implies a change that is significant and not ad hoc or temporal. This is exemplified by the World Energy Council Deutschland's definition of energy transition as a 'long-term structural change in energy systems' [2]. This definition is inclusive but somewhat general. It reminds us of how early modelers such as Naill (1977) [6] defined the term when it was coined. The second category defines energy transition as a transition towards greener energy [7]. This is exemplified by IRENA's definition of the term as a 'pathway towards transformation of the global energy sector from fossil-based to zero-carbon by the second half of this century' [8]. This definition is more specific. The term 'sustainability/ sustainable' is sometimes added to distinguish this green energy definition from the earlier somewhat more general definition. Although energy governance discussions go further to include many other aspects of energy (such as access, affordability, equity and justice) as all vital elements of a country's energy system, this article does not include these other elements in the definition of sustainable energy transition in order to maintain analytical focus. In terms of further conceptualization of the term, Edomah et al. (2020) [9] provide an insightful socio-technical typology for national energy transitions. They distinguish between 'Interim energy transition', where there are governmental green energy policies but no public acceptance and support; 'Deliberate energy transition' where citizens/users drive sustainable energy transitions even when there are no supporting governmental policies; and 'Transformative energy transition' where sustainable energy transition is motivated by a combination of government policy and public action [9]. York and Bell (2019) also provide an insightful conceptual dichotomy between energy transition and addition [10]. This conceptualization is particularly useful in Global South contexts where low electricity access necessitates continued investments in non-renewable energy, even when these countries make investments in renewable energy; raising the question of whether expansions in green energy in such contexts constitute energy transitions or rather mere additions.

The literature contains two principal motivations for energy transition: firstly, to secure energy supply, e.g., the energy transition in the United States of America to reduce import dependency; and the energy transitions in China and South Africa for expanding the supply to meet the rising energy demand; and secondly, to respond to environmental concerns such as the climate change, e.g., the energy transition in Germany based on environmental concerns [2]. Likewise, Hauff et al. (2014) identified two drivers for energy transition [2]. The first is government policy, e.g., renewable energy targets, energy efficiency standards and associated incentives. The second are technological innovation and business strategies of energy companies, e.g., the US "shale gas revolution" based on shale gas technological innovations. Of the two drivers, government policy is recognized to be the main driver of energy transition $[2,11]$.

In Ghana, energy transition as a research theme is new. There is no conclusive research knowledge with regards to whether energy transition has occurred or not, and in what form if it has occurred. Against this background, this overview paper provides insights into electrical energy transition in the context of Ghana. It contributes answers to the research question: How has electrical energy transition manifested in the context of Ghana?

\section{Indicators of energy transition}

In assessing if electrical energy transition has occurred in Ghana and how, indicators of energy transition were deduced from the literature to help arrive at this conclusion. This section presents some indicators of energy transition found in the literature.

Change in energy source type This refers to the transition in the energy source type, for instance from thermal or nuclear sources to greener sources such as solar or wind energy. This is a widespread indicator found in the literature about energy transition $[1,2,6,12]$. It also includes a change within the same category of an energy source, e.g., a change from coal to natural gas, as both are thermal energy sources. Also admissible in this indicator category is the ongoing transition in domestic energy from biomass energy to more modern energy sources such as liquefied petroleum gas in developing countries $[13,14]$.

Change in energy ownership and management This refers to the change in the ownership or management of a country's energy system, for instance from state to private energy or from centralized energy to localized energy or vice versa [15-19]. The transition from centralized energy to localized energy has been termed 'democratization of energy' [15].

Transition to greener vehicular transportation This refers to a transition to greener vehicular transportation, and takes the energy transition discussion beyond domestic and industrial energy to energy transition occurring in vehicular transportation [1, 2, 12, 20, 21]. 
This is important because the transportation sector is a major consumer of energy [22, 23].

\section{Methods}

Information about Ghana's electrical energy transition was obtained through thematic content analysis of Ghana's renewable energy policy documents, namely the Ghana Renewable Energy Act (2011) and the Ghana Renewable Energy Master Plan (2019); energy sector reports; newspaper articles; and information on the websites of Ghana's energy sector institutions such as the Energy Commission, Volta River Authority, Electricity Company of Ghana and the Northern Electricity Distribution Company. Relevant pieces of information were deduced and organized according the themes: (1) Proportions of Ghana's electrical energy produced from hydro, thermal, solar and other sources; (2) Proportions of Ghana's electrical energy obtained from state and private sources'; and (3) Structural changes that have occurred in Ghana's electrical energy system over the years. From electrical energy supply figures in the energy sector reports, a summary table of Ghana's 2020 electrical energy sources from state and private sources was constructed (Table 1). The proportions of the 2020 electrical energy mix which are hydro, thermal and solar sources were computed from Table 1 . The indicators of energy transition presented in "Indicators of energy transition" provided guidance in concluding on how energy transition has occurred in the context of Ghana.

\section{Results}

\section{Ghana's electricity supply: origins and highlights}

State-operated electricity supply in Ghana dates back to 1914 under the then colonial government. These were fossil-powered stations that supplied limited electricity to selected cities such as Takoradi, Koforidua, Accra, Kumasi, Tamale, Cape Coast, Winneba and Tema [24, 25]. The biggest of these stations, the Tema diesel power station, had a generation capacity of 35,298 kilowatts. The first grid electricity transmission system was installed in 1963. It was a $161 \mathrm{kV}$ transmission system to transmit electricity from the Tema power station to mostly Accra.

Table 1 Ghana 2020 electricity generation sources [Constructed from Energy Commission (2020)]

\begin{tabular}{|c|c|c|c|}
\hline Plant & Installed capacity (MW) & Dependable capacity (MW) & Fuel type \\
\hline \multicolumn{4}{|c|}{ Supply from the State Volta River Authority } \\
\hline Akosombo GS & 1020 & 900 & Hydro \\
\hline Kpong GS & 160 & 140 & Hydro \\
\hline TAPCO (T1) & 330 & 300 & LCO/Gas (Thermal) \\
\hline TICO (T2) & 340 & 320 & LCO/Gas (Thermal) \\
\hline TT1PP & 110 & 100 & LCO/Gas (Thermal) \\
\hline TT2PP & 87 & 70 & Gas (Thermal) \\
\hline KTPP & 220 & 200 & Gas/ Diesel (Thermal) \\
\hline VRA Solar Plant & 2.5 & 1.75 & Solar \\
\hline Total state supply & 2269.5 & 2031.75 & \\
\hline \multicolumn{4}{|c|}{ Supply from private power companies (Independent Power producers) } \\
\hline Bui GS & 404 & 360 & Hydro \\
\hline CENIT & 110 & 100 & LCO*/Gas (Thermal) \\
\hline AMERI & 250 & 230 & Gas (Thermal) \\
\hline SAPP 161 & 200 & 180 & Gas (Thermal) \\
\hline SAPP 330 & 360 & 340 & LCO*/Gas (Thermal) \\
\hline KAR power & 470 & 450 & $\mathrm{HFO}^{*}$ (Thermal) \\
\hline AKSA & 370 & 350 & HFO* (Thermal) \\
\hline BXC solar & 20 & 14 & Solar \\
\hline Meinergy solar & 20 & 14 & Solar \\
\hline Trojan & 44 & 39.6 & Diesel/Gas (Thermal) \\
\hline Genser & 89.5 & 18 & Gas (Thermal) \\
\hline CEN power & 340 & 340 & LCO*/Gas (Thermal) \\
\hline Amandi & 190 & 190 & LCO*/Gas (Thermal) \\
\hline Total IPP supply & 2867.5 & 2625.6 & \\
\hline Total (State and Private) & 5137.0 & 4657.35 & \\
\hline
\end{tabular}

* LCO light crude oil, HFO heavy fuel oil 
The inauguration of the Akosombo hydroelectric power station in 1966 by the then independent Ghana Government marked a significant turning point in Ghana's electricity sector. This large dam project resulted in the creation of one of the world's largest man-made lakes, the Volta Lake. It is about $500 \mathrm{~km}$ long and covers a land area of about $8500 \mathrm{~km}^{2}$. The Akosombo hydropower station has a generation capacity of about 1000 megawatts $(\mathrm{MW})$. At the time of its inauguration, about $60 \%$ of the electricity output was used to power the smelter of the Volta Aluminum Company Limited. The remaining provided almost all of Ghana's grid electricity. Ghana's population was then about 5 million compared to the present population of about 30 million people. Moreover, the rural population who were in the majority had not been connected to the national grid. There was even surplus energy that was exported to the neighboring countries Togo, Benin and Burkina Faso. With an increase in electricity demand as a result of the increasing population, increasing industries and expansion of grid electricity to rural areas, the power supply from the Akosombo hydroelectric power station became inadequate. The supply shortfall has been addressed over the years through addition of smaller hydroelectric stations and thermal power stations to the national grid.

\section{Ghana's electricity supply: present situation}

Off-grid electricity is presently only at the experimental stage in Ghana. The section therefore highlights the situation as pertains to grid electricity. Ghana's present electricity sector has three major actors: electricity producers, a transmitter company and distributers. The power producer category comprises both state companies and private companies. The state power producer is the Volta River Authority (VRA). It owns and operates the Akosombo hydroelectric power station, the Kpong hydroelectric power station, five thermal power stations and one solar plant. All in all, the state-operated power stations have a present installed capacity of $2269.5 \mathrm{MW}$ and a dependable capacity of $2031.75 \mathrm{MW}$ [26]. The private power producers are termed Independent Power Producers (IPPs). They are mostly foreign companies. The major IPPs are twelve thermal power stations and one hydropower station (see details in Table 1), with a total installed capacity of $2867.5 \mathrm{MW}$ and a total dependable capacity of $2625.6 \mathrm{MW}$ [26]. This energy is sold to the state for onward transmission and distribution. Table 1 provides further details of the situation of electricity supply from state and private producers as of 2020.

For 2020, the peak electricity demand reached 2957 MW, a marginal increase compared to the 2019 peak demand of $2665.68 \mathrm{MW}$ [26]. The total dependable grid capacity amounted to $4657.35 \mathrm{MW}$ : approximately $30 \%$ hydro, approximately $69 \%$ thermal and about $0.64 \%$ solar energy; and approximately $44 \%$ state and approximately $56 \%$ private (see Table 1 ).

The electricity transmitter category is a State company called Ghana Grid Company Limited (GRIDCO). It operates high voltage electricity lines that convey electrical power from the production areas to cities and towns where the power is consumed. The power distribution category is composed of two state companies: the Electricity Company of Ghana (ECG), which is responsible for electricity distribution in the southern and middle parts of Ghana, and the Northern Electricity Company Limited (NEDCO), which is responsible for electricity distribution in the northern part of Ghana. These two companies are responsible for bringing down the high voltages of the transmitted electricity to consumption voltages, distributing the power to homes and industries, and collecting revenues from the power users. There was an attempt in 2019 to privatize electricity distribution in Ghana, but controversies surrounding the privatization stalled the process.

When the present situation of Ghana's grid electricity situation is compared to situations in the past, two structural changes can be seen: (1) Transition from an exclusively hydroelectric energy to a hydro-thermal mix, with thermal energy constituting approximately $69 \%$ of 2020 production; and (2) Transition from an exclusively state supply to a state-private supply mix, with approximately $56 \%$ of supply coming from private companies as of 2020 (Table 1). These changes have been motivated by the need to expand the energy supply to meet the increasing demand of $10-15 \%$ per annum from increasing population, industries and grid expansion. Additional thermal plants and private electricity producers have mostly been brought on board during periods when the nation had run into power crisis. Ghana's unstable electricity problems started as far back as 2001. It however peaked in 2014 and 2015, partly due to prolonged dry seasons during the period resulting in decreased electricity generation from the Akosombo hydroelectricity station. In 2015, the blackouts were so severe that the term 'dumsor', literally meaning 'power off and on' became a household term in Ghana. As quick fix, the then Government entered into a 10-year contract with the Turkish Karadeniz Energy Group for the provision of thermal electricity from two floating power ships. The agreement did not require Ghana to pay the upfront cost for the power ships but rather for the about $450 \mathrm{MW}$ electricity to be fed into the national grid.

The increasing transition to thermal electricity in Ghana has been accompanied by astronomical increases in electricity prices over the years. This is well captured 
in a remark by Pratt (2016) during a radio discussion on Adom FM in 2016 [27]:

"How can electricity bill that was around GHC 300 move to GHC 1200, when I complained, it jumped to GHC 1800; while we were still deliberating on this, it shot up to GHC 2000 something. The bill that was brought last month was just too serious, it was GHC 6000, I don't even know whether to cry or to laugh about this,"-Kwasi Pratt, Managing Editor of the Insight newspaper.

There is no written government policy driving the increasing transition from hydro power to thermal power. The increasing transition from state power production to private production is backed by a general government policy of public-private partnerships for infrastructure and improved public services delivery, which is enshrined in a written National Policy on Public-Private Partnerships (2011).

With respect to vehicular transportation, there has been no change in heavy reliance on fossil energy [28]. Almost all the vehicles in Ghana presently run on fossil fuels. A very small proportion have hybrid drive systems that run on both fossil fuel and electrical energy stored in traction batteries. Even then, these hybrid cars mostly depend on fossil fuel to charge the traction batteries because public electric car charging ports are not available.

\section{Ghana's renewable energy agenda}

New renewable energy has attracted attention in policy, with policy targets such as $10 \%$ of renewable energy in Ghana's energy mix by 2030 (Renewable Energy Act, 2011), and renewable energy to 1,000 off-grid communities by 2030 (Renewable Energy Master Plan, 2019). There is however limited action on the ground towards achievement of these new renewable energy targets. There are scattered solar energy projects in Ghana by both state and non-state companies. However, Ghana has not moved beyond demonstration projects on solar and other new renewable energy to large-scale adoption. New renewable energy presently accounts for less than $1 \%$ of the grid energy mix (see Table 1). Ghana's larger scale hydroelectricity projects (of over $100 \mathrm{MW}$ ) are not considered here, as the Ghana Renewable Energy Act (2011) considers only hydropower projects of up to a $100 \mathrm{MW}$ capacity as renewable energy.

\section{Discussions}

Clearly, there have been structural changes in Ghana's electricity sector, in the form of a transition from hydro energy to a hydro-thermal mix with thermal presently accounting for a higher proportion of Ghana's grid electricity; and transition from an exclusively stateproduced electricity to a state-private supply mix with private companies presently accounting for a higher proportion of Ghana's electricity production. These transitions were motivated by the need to expand the energy supply to meet the increasing demand and driven by a general government policy of public-private partnerships for infrastructure and public services delivery. This Ghanaian experience of energy transition is comparable to the energy transitions in China and South Africa, where the transitions were also motivated by the need to expand supply to meet the increasing demand [2].

The increasing transition from hydroelectricity to thermal electricity is unexpected, given the comparative advantages hydroelectricity has over thermal electricity and also the somewhat global consensus on the need to move towards greener energy sources [29-33]. Besides the comparative environmental advantages of hydroelectricity in terms of lower carbon emissions and lower pollution to host communities, hydroelectricity is cheaper for the power consumer compared to thermal electricity [34]. This is so because hydroelectricity relies on flowing water to run the plant turbines whereas thermal electricity relies on expensive fossil fuels to run the plants. Ghana's thermal plants mostly run on light crude oil and gas (See Table 1).

For a developing country such as Ghana, environmental concerns are not always considered in the pursuit of economic and development aspirations. This can be seen in the widespread occurrence of livelihood practices such as artisanal mining of minerals and sand that continue to happen even though they cause massive environmental destruction [35-39]. It is nevertheless expected that the price cost to citizens shall be an important consideration in choosing between development pathway options, given the generally low levels of wages and salaries. One may therefore wonder why successive governments have over the years resorted to the more expensive thermal energy option in addressing Ghana's electricity shortfalls rather than investing in alternative cheaper renewable energy. The answer lies in Government's tendency to resort to 'quick fix' solutions in addressing societal problems. Hydroelectricity projects are highly capital intensive and take a considerable period of time to come to fruition. Since the Akosombo dam project, Ghana has constructed two additional hydroelectric dams (see Table 1). The most recent is the Bui dam, a 400-megawatt hydroelectric project completed in 2013 through the publicprivate partnership between the Ghana Government and Sino Hydro, a Chinese company [40]. The project cost 622 million USD and took over 50 years since its inception to be completed. The cost and long duration make such projects unattractive to governments with 4-year 
mandates and limited funds. The thermal energy option has thus been more appealing to governments over the years because it provides a quicker fix and reliable solution that enables governments to be seen by the citizenry to have provided solutions during their four-year terms, and thus earn them political points which they need to remain in power. For instance, the Government's decision to resort to floating thermal power ships to address the 2014 and 2015 power crisis could be explained by the fact that the already assembled power plants could be sailed to Ghana and connected to the national grid within weeks $[41,42]$.

The increasing transition from state electricity production to production by private companies is not surprising. There is a general Ghana Government policy to partner private entities in the quest to deliver infrastructure and social services, necessitated by the limited state financial resources against the high public demand for infrastructure and social services [43]. Public privatepartnerships are presumed to enable governments to deliver the essential infrastructure and public services effectively. These presumed benefits have made publicprivate partnerships appealing not only in Ghana, but in many countries across the globe, particularly in developing countries [44-46]. There is however overwhelming evidence to the fact that public private partnerships have largely failed to deliver the presumed benefits of secured and better public services [44, 47-50]. In the Ghanaian electricity sector, the public-private partnerships have resulted in a present excess electricity generation capacity: 4657.35 MW production as against a 2020 peak demand of 2957 MW. Many stakeholders have raised concerns about the nature of contracts the state has made with the private power producers which require Ghana to pay for the excess power whether the power is used or not. It has been reported that Ghana presently pays about $\$ 450$ million yearly for the unused excess power from the private producers [51]. This cost is passed on to consumers and contributes to the high cost of electricity. Even with the excess generation capacity, there have been periods of sporadic power supply caused by the government's inability to pay the private power producers and suppliers of the fossil fuels used for running the plants. The present generation overcapacity constitutes a setback to transition towards greener electrical energy in Ghana, as it will be difficult to justify further investments in electricity production when there is already generation overcapacity. The higher cost of thermal energy however provides a justification for investment in cheaper renewable energy. Considering the political cost of expensive energy and Ghana's accumulating energy sector debt of over $\$ 2$ billion, it can be expected that the Government would be interested if provided with electrical power alternatives that are reliable, cheaper and deliverable within a four-year term through public-private partnership arrangements.

The heavy reliance on fossil fuels for vehicular transportation can be expected to remain the same into the foreseeable future. This is so because the charging point infrastructure required for electric cars are presently not available in the country [28]. Furthermore, there is presently little public consciousness on switching to greener vehicular transportation. Studies on vehicular transportation preferences in Ghana indicate that other factors such as income level, family status and size, comfort and distance from workplace determine people's vehicular transportation preferences [52, 53]. Environmental concern is not a major consideration.

\section{Conclusions}

From the study findings and accompanying discussions, it can be concluded that energy transition in its broad sense of structural changes in a country's electrical energy system has occurred in Ghana in the form of a transition from exclusive hydro energy to a hydro-thermal mix with thermal presently accounting for a higher proportion of Ghana's grid electricity; and a transition from an exclusively state production to a state-private supply mix, where private companies presently account for the higher proportion of Ghana's electricity production. These transitions were motivated by the need to expand the energy supply to meet the increasing demand and driven by a general government policy of public-private partnerships for infrastructure and public service delivery. However, this Ghanaian situation of energy transition cannot be said to be transition towards greener energy. Thus, sustainable energy transition has not occurred in Ghana. It is recommended that further studies should be conducted on why Ghana's new renewable energy agenda has so far only been an agenda in policy with very minimal implementation in practice.

\section{Abbreviations \\ ECG: Electricity Company of Ghana; GRIDCO: Ghana Grid Company Limited; HFO: Heavy fuel oil; IPPs: Independent power producers; IRENA: International Renewable Energy Agency; LCO: Light crude oil; MW: Megawatt; NEDCO; Northern Electricity Company Limited; VRA: Volta River Authority.}

\section{Acknowledgements}

The content of this paper is based on an independent study conducted by the authors. It relied heavily on secondary data regarding Ghana's 2020 electricity supply situation available on the websites of Ghana's energy sector institutions. The authors are grateful to Ghana's energy sector institutions, particularly the Energy Commission, for making information available and accessible via the institutional website. They are also grateful to Yvonne Yemoh for language proof reading and edits. And finally, they are indebted to the anonymous reviewers for the very useful review comments and suggestions. Moreover, they would like to thank the Convenors of the MIASA Interdisciplinary Fellow Group (IFG) 4 for coordinating the 'Special Issue' in 
which this article is being published and for coordinating the reviews of earlier drafts of this paper.

\section{Authors' contributions}

All authors contributed to the development, revision and finalization of the article. All authors read and approved the final manuscript.

\section{Funding}

No study received no funding.

\section{Availability of data and materials}

The datasets supporting the conclusions of this article are included within the article.

\section{Declarations}

Ethics approval and consent to participate

Not applicable.

\section{Consent for publication}

Not applicable.

\section{Competing interests}

The authors declare that they have no competing interests.

Received: 28 January 2021 Accepted: 19 November 2021

Published online: 03 December 2021

\section{References}

1. Gallo AB, Simões-Moreira JR, Costa HKM, Santos MM, Moutinho dos Santos EM (2016) Energy storage in the energy transition context: a technology review. Renew Sustain Energy Rev 65:800-822. https://doi.org/10. 1016/j.rser.2016.07.028

2. Hauff J, Bode A, Neumann D, Haslauer F (2014) Global Energy Transitions: a comparative analysis of key countries and implications for the international energy debate. World Energy Council Weltenergierat-Deutschland. Berlin

3. Smil V (2010) Energy transitions: history, requirements, prospects. Praeger, ABC-CLIO

4. Verbong G, Loorbach D (2012) Governing the energy transition: reality, illusion or necessity?, Governing the energy transition: reality, illusion or necessity? Routledge. https://doi.org/10.4324/9780203126523

5. Guan D, Meng J, Reiner DM, Zhang N, Shan Y, Mi Z, Shao S, Liu Z, Zhang Q, Davis SJ (2018) Structural decline in China's $\mathrm{CO}_{2}$ emissions through transitions in industry and energy systems. Nat Geosci 11(8):551-555. https://doi.org/10.1038/s41561-018-0161-1

6. Naill RF (1997) Managing the energy transition: a system dynamics search for alternatives to oil and gas. [COAL2 model]

7. Gibbs D, O'Neill K (2015) Building a green economy. Sustainability transitions in the UK building sector. Geoforum 59:133-141. https://doi.org/10. 1016/j.geoforum.2014.12.004.1

8. IRENA (2020) Energy Transition. https://www.irena.org/energytransition. Accessed 5 Sept 2020

9. Edomah N, Bazilian M, Sovacool BK (2020) Sociotechnical typologies for national energy transitions. Environ Res Lett. https://doi.org/10.1088/ 1748-9326/abba54

10. York R, Bell SE (2019) Energy transitions or additions?: Why a transition from fossil fuels requires more than the growth of renewable energy. Energy Res Soc Sci. https://doi.org/10.1016/j.erss.2019.01.008

11. Bridge G, Bouzarovski S, Bradshaw M, Eyre N (2013) Geographies of energy transition: space, place and the low-carbon economy. Energy Policy 53:331-340. https://doi.org/10.1016/j.enpol.2012.10.066

12. Şanlı B (2017) What is the speed of energy transition. Energy Policy Turkey 3(2017):64-74

13. Leach $G$ (1992) The energy transition. Energy Policy 20(2):116-123. https://doi.org/10.1016/0301-4215(92)90105-B
14. Pachauri $S$, Jiang $L$ (2008) The household energy transition in India and China. Energy Policy 36(11):4022-4035. https://doi.org/10.1016/j.enpol. 2008.06.016

15. Burke MJ, Stephens JC (2018) Political power and renewable energy futures: a critical review. Energy Res Soc Sci 35:78-93. https://doi.org/ 10.1016/j.erss.2017.10.018

16. Rommel J, Radtke J, Von Jorck G, Mey F, Yildiz Ö (2018) Community renewable energy at a crossroads: a think piece on degrowth, technology, and the democratization of the German energy system. J Clean Prod 197:746-1753. https://doi.org/10.1016/j.jclepro.2016.11.114

17. Klagge B, Meister T (2018) Energy cooperatives in Germany-an example of successful alternative economies. Local Environ 23(7):697-716. https://doi.org/10.1080/13549839.2018.1436045

18. Yadoo A, Cruickshank H (2010) The value of cooperatives in rural electrification'. Energy Policy 38(6):2941-2947. https://doi.org/10.1016/j. enpol.2010.01.031

19. Melo É, De Almeida Neves EM, Pazzini LHA (2011) The Brazilian electricity model: An overview of the current structure and market design. In 2011 8th International Conference on the European Energy Market, EEM 11:592-597. https://doi.org/10.1109/EEM.2011.5953081

20. Nilsson M, Nykvist B (2016) Governing the electric vehicle transitionNear term interventions to support a green energy economy. Appl Energy 179:1360-1371. https://doi.org/10.1016/j.apenergy.2016.03.056

21. Silvia C, Krause RM (2016) Assessing the impact of policy interventions on the adoption of plug-in electric vehicles: an agent-based model. Energy Policy 96:105-118. https://doi.org/10.1016/j.enpol.2016.05.039

22. Yin X, Chen W, Eom J, Clarke LE, Kim SH, Patel PL, Yu S, Kyle GP (2015) China's transportation energy consumption and CO2 emissions from a global perspective. Energy Policy 82(1):233-248. https://doi.org/10. 1016/j.enpol.2015.03.021

23. Energy Information Administration (EIA) (2016) Transportation Sector Energy Consumption. International Energy Outlook 2016. http://www. eia.gov/beta/MER/index.cfm?tbl=T02.05\#/?f=A\&start=1995\&end= 2014\&charted=9-7-3-4. Accessed 15 Oct 202

24. Clark NL (1994) Electrical power. A country study: Ghana. Library of Congress Federal Research Division

25. Eshun ME, Amoako-Tuffour J (2016) A review of the trends in Ghana's power sector. Energy Sustain Soc. https://doi.org/10.1186/ s13705-016-0075-y

26. Energy Commission (2020) 2020 Electricity Supply Plan for the Ghana Power System: a mid-year review. https://energycom.gov.gh/files/ 2020\%20Supply\%20Plan\%20Mid\%20Year\%20Review.pdf. Accessed 14 Sept 2020

27. Pratt K (2016) Government must be forced to reduce electricity bills, Ghanapoliticsonline.com. https://ghanapoliticsonline.com/govt-mustforced-reduce-electricity-bills-pratt/. Accessed 14 Sept 2020

28. Ayetor GK, Quansah DA, Adjei EA (2020) Towards zero vehicle emissions in Africa: a case study of Ghana. Energy Policy 43:111606. https:// doi.org/10.1016/j.enpol.2020.111606

29. Miescher SF, Tsikata D (2009) Hydro-power and the promise of modernity and development in Ghana: comparing the Akosombo and Bui dam projects. Ghana Stud 12(13):15-53

30. Akpinar A (2013) The contribution of hydropower in meeting electric energy needs: the case of Turkey. Renew Energy 51:206-219. https:// doi.org/10.1016/j.renene.2012.09.049

31. Bahadori A, Zahedi G, Zendehboudi S (2013) An overview of Australia's hydropower energy: status and future prospects. Renew Sustain Energy Rev 20:565-569. https://doi.org/10.1016/j.rser.2012.12.026

32. Killingtveit $\AA$ (2013) Hydroelectric power. In: Letcher $T$ (ed) Future energy: improved, sustainable and clean options for our planet, 2nd edn. Elsevier. https://doi.org/10.1016/B978-0-08-099424-6.00021-1

33. Bagher AM, Vahid M, Mohsen M, Parvin D (2015) Hydroelectric energy advantages and disadvantages. Am J Energy Sci 2(2):17-20

34. Fakehinde OB, Fayomi OS, Efemwenkieki UK, Babaremu KO, Kolawole DO, Oyedepo SO (2019) Viability of hydroelectricity in Nigeria and the future prospect. Energy Procedia 157:871-878. https://doi.org/10. 1016/j.egypro.2018.11.253

35. Mensah JV (1997) Causes and effects of coastal sand mining in Ghana. J Trop Geogr 18(1):69-88. https://doi.org/10.1111/1467-9493.00005 
36. Bonzongo JC, Nartey VK, Donkor AK (2003) Environmental impacts of mercury related to artisanal gold mining in Ghana. J Physique IV (Proceedings):217-220

37. Hilson G (2011) Artisanal mining, smallholder farming and livelihood diversification in rural sub-Saharan Africa: an introduction. J Int Dev 23(8):1031-1041

38. Agyei-Mensah S, Oteng-Ababio M (2012) Perceptions of health and environmental impacts of e-waste management in Ghana. Int J Environ Health Res 22(6):500-517. https://doi.org/10.1080/09603123.2012.667795

39. Obiri S, Mattah PA, Mattah MM, Armah FA, Osae S, Adu-Kumi S, Yeboah PO (2016) Assessing the environmental and socio-economic impacts of artisanal gold mining on the livelihoods of communities in the Tarkwa Nsuaem municipality in Ghana. Int J Environ Res Public Health 13(2):1-15

40. Kirchherr J, Disselhoff T, Charles K (2016) Safeguards, financing, and employment in Chinese infrastructure projects in Africa: the case of Ghana's Bui Dam. Waterlines. https://doi.org/10.3362/1756-3488.2016.005

41. Kumi EN (2017) The electricity situation in Ghana: challenges and opportunities, CGD policy paper. https://www.cgdev.org/publication/elect ricity-situation-ghana-challenges-and-opportunities. Accessed $10 \mathrm{Sept}$ 2020

42. Gyamfi S, Diawuo FA, Kumi EN, Sika F, Modjinou M (2018) The energy efficiency situation in Ghana. Renew Sustain Energy Rev 82(1):1415-1423. https://doi.org/10.1016/j.rser.2017.05.007

43. Robert OK, Dansoh A, Ofori-Kuragu JK (2014) Reasons for adopting public-private partnership (PPP) for construction projects in Ghana. Int J Constr Manag 14(4):227-238. https://doi.org/10.1080/15623599.2014. 967925

44. Jamali D (2004) Success and failure mechanisms of public private partnerships (PPPS) in developing countries. Insights from the Lebanese context. Int J Public Sect Manag 17(5):414-430. https://doi.org/10.1108/ 09513550410546598

45. Nsasira R, Basheka BC, Oluka PN (2013) Public private partnerships (PPPs) and enhanced service delivery in Uganda: implications from the energy sector. Int J Bus Adm 4(3):48-60. https://doi.org/10.5430/ijba.v4n3p48

46. Sapri M, Hariati AH, Ting LS, Sipan I (2016) Public private partnership benefits in delivering public facilities in Malaysia. In: MATEC Web of Conferences. EDP Science. https://doi.org/10.1051/matecconf/20166600014
47. Van Dijk MP (2008) Public-private partnerships in basic service delivery: impact on the poor, examples from the water sector in India. Int J Water 4(4):216-234. https://doi.org/10.1504/IJW.2008.019495

48. Hall D (2015) Why public-private partnerships don't work: the many advantages of the public alternative. Public Services International Research Unit. Available via https://apo.org.au/. Accessed 19 Sept 2020

49. Pusok K (2016) Public-private partnerships and corruption in the water and sanitation sectors in developing countries. Polit Res Q 69(4):678-691. https://doi.org/10.1177/1065912916658552

50. Tariq S, Zhang X, Leung RHM (2019) An analytical review of failed water public-private partnerships in developing countries. Proc Inst Civ Eng Manag Procure Law 172(2):60-69. https://doi.org/10.1680/jmapl.18.00042

51. Dzawu MM, Vuuren, AJ Van (2019) Energy surplus leaves Ghana paying for unneeded power. https://www.bloomberg.com/news/articles/201911-08/how-having-too-much-energy-creates-a-debt-problem-for-ghana. Accessed 12 Sept 2020

52. Abane A (1993) Mode choice for the journey to work among formal sector employees in Accra, Ghana. J Transp Geogr 1(4):219-229. https://doi. org/10.1016/0966-6923(93)90046-3

53. Amoh-Gyimah R, Aidoo EN (2013) Mode of transport to work by government employees in the Kumasi metropolis, Ghana. J Transp Geogr 31:35-43. https://doi.org/10.1016/j.jtrangeo.2013.05.008

54. Forkuor D, Otieku E (2015) Environmental consciousness and practices of land users along urban water bodies in Ghana: the case of Kumasi Metropolis. Ethiop J Environ Stud Manag 8(2):966-975. https://doi.org/10. 4314/ejesm.v8i0.10s

55. Amoah A, Hughes G, Pomeyie P (2018) Environmental consciousness and choice of bulb for lighting in a developing country. Energy Sustain Soc 8(17):1-9. https://doi.org/10.1186/s13705-018-0159-y

56. Osuteye ENN (2015) Environmentalism in Ghana: the rise of environmental consciousness and movements for nature protection. Disertation, University of Kent. https://kar.kent.ac.uk/47995/. Accessed 8 Sept 2020

\section{Publisher's Note}

Springer Nature remains neutral with regard to jurisdictional claims in published maps and institutional affiliations.
Ready to submit your research? Choose BMC and benefit from:

- fast, convenient online submission

- thorough peer review by experienced researchers in your field

- rapid publication on acceptance

- support for research data, including large and complex data types

- gold Open Access which fosters wider collaboration and increased citations

- maximum visibility for your research: over $100 \mathrm{M}$ website views per year

At BMC, research is always in progress.

Learn more biomedcentral.com/submissions 